\title{
Zinc and boron nutrition in pulses: A review
}

\author{
Anju B. Raj \\ Kerala Agricultural University, Department of Agronomy, College of Agriculture, Vellayani- \\ 695522 (Thiruvananthapuram), India \\ Sheeja K. Raj* \\ Kerala Agricultural University, Department of Agronomy, College of Agriculture, Vellayani- \\ 695522 (Thiruvananthapuram), India \\ *Corresponding author. E-mail: sheejakraj70@gmail.com

\begin{abstract}
$\mathrm{Zn}$ plays major role in many physiological processes viz., chlorophyll formation, pollen formation, fertilization, protein synthesis, cell elongation, nodule formation etc. Hence, $\mathrm{Zn}$ nutrition favourably influences the growth, yield, physiological parameters and nodule formation in pulses. Similar to that of $\mathrm{Zn}, \mathrm{B}$ also plays a major role in the functioning of reproductive tissues, structural integrity of plasma membrane, sugar transport, nodule development etc. Boron nutrition reduces the flower drop, increases the pod setting in pulses and also increased nodulation in pulses. The review elaborates the effect of $\mathrm{Zn}$ and $B$ nutrition on the physiological, growth and yield parameters and yield of pulses and their effect on nodule formation and uptake of nutrients in pulses.
\end{abstract}

Keywords: Boron, Growth, Nodule, Nutrient Uptake, Physiological, Yield, Zinc

\section{Article Info}

https://doi.org/10.31018/ jans.v11i3.2157

Received August 3, 2019

Revised: August 29, 2019

Accepted: September 1, 2019

\section{How to Cite}

Raj, A.B. and Raj, S.K. (2019). Zinc and boron nutrition in pulses: A review. Journal of Applied and Natural Science, 11(3): 673 - 679 https:// doi.org/10.31018/ jans.v11i3.2157

\section{INTRODUCTION}

Zinc plays a major role in plant growth and development. Stevenson and Cole (1999) reported that a healthy plant contain 27 to $150 \mathrm{mg} \mathrm{Zn} \mathrm{kg}^{-1}$ plant biomass. Deficiency of $\mathrm{Zn}$ causes chlorosis, sterility, reduction in leaf size and reduction in spikelet number (Cakmak, 2000). Zinc also have a significant role in plant metabolism and synthesis of auxins, carbohydrate, phosphate and nucleic acid (Latef et al., 2017).

Zinc is an important constituent of enzymes and proteins. It is the only metal element present in all the six enzyme classes, oxidoreductases, transferases, hydrolases, lyases, isomerases and ligases (Auld, 2001). It also acts as the co-factor of enzymes and stabilizes the structure of proteins (Evans and Halliwell, 2001). It also plays a vital role in stomatal regulation and maintaining an ionic balance in plant system (Baybordi, 2006). Zinc is also involved in chlorophyll production, pollen function, fertilization and germination (Pandey et al., 2006; Cakmak, 2008).

Zinc content in newly developed radicles and coleoptiles were much higher up to $200 \mathrm{mg} \mathrm{kg}^{-1}$ (Ozturk et al., 2006). The high concentration of $\mathrm{Zn}$ indicates the role of $\mathrm{Zn}$ in physiological processes viz., protein synthesis, cell elongation, membrane function and resistance to abiotic stresses in early seedling development. Marschner (1995) reported that higher seed $\mathrm{Zn}$ content during germination and seedling development stage expressed great- er resistance to soil-borne pathogens, thus ensured good crop stand and better yield.

Boron is considered to be an essential micronutrient element for plant growth and development. Boron deficiency leads to several physiological damages in plant. It is considered to be essential for sugar transport, synthesis of cell wall, cell wall structure, metabolism of carbohydrate, RNA, phenol and indole acetic acid, respiration and membrane integrity (Parr and Loughman, 1983). It is essential for maintaining the structural integrity of plasma membrane. Boron enhanced the uptake of $\mathrm{K}^{+}$ion and membrane bound ATPase activity which caused the hyperpolarization of plasma membrane. Serrano (1989) observed that the driving force for $\mathrm{K}^{+}$influx was increased by the pumping activity of membrane and hyperpolarization. Schon et al. (1990) observed an enhancement in the opening and closing of stomata by increased $\mathrm{K}^{+}$ion influx due to boron in dayflower (Commelina communis). Cheng and Rerkasem (1993) opined that plasma membranes are highly leaky and lost their structure due to B deficiency. Boron is involved in the functioning of plant reproductive tissues. Marschner (1995) reported that B is found to be essential for pollen tube germination, cell elongation, cell division, male flower sterility and fruit and seed formation in plants. Aslam et al. (2002) reported that B nutrition leads to better pollination, seed setting and lower spikelet sterility, which finally contributed to higher grain yield in rice cultivars. Tariq and Mott (2007) pointed out 
that $B$ deficiency during flowering prevents the pollen tube growth which causes pollen sterility, flower drop and poor pod setting. Boron deficiency was more under dry weather and low moisture conditions and its deficiency reduced the number of pollen grains, pollen germination and filling up of grains. It was also observed that foliar nutrition of $\mathrm{B}$ enhanced the flower development, pollen grain formation, pollen viability, pollen tube growth and seed development in green gram (Praveena et al., 2018).

Rerkasem (1996) reported that the growing points viz., root tips, new leaves and buds required higher amount of $B$ than mature tissues. Dell and Huang (1997) pointed out that B deficiency in soil retards root elongation, cell division in the root tip, leaf expansion and reduction in photosynthesis. Boron is also involved in root growth (Moeinian et al., 2011) and impart stress tolerance in plant and enhances grain production (Hussain et al., 2012).

Effect of $\mathrm{Zn}$ and $\mathrm{B}$ nutrition on physiological parameters of pulses: Tripathy et al. (1999) reported that soil application of zinc $25 \mathrm{~kg} \mathrm{ha}^{-1}+\mathrm{B}$ $10 \mathrm{~kg} \mathrm{ha}^{-1}$ recorded significantly higher leaf area index (LAI) in soybean. In mung bean foliar application of one per cent $\mathrm{Zn}$ recorded significantly higher LAl (Mondal et al., 2011). Thamke (2017) pointed out that $\mathrm{Zn}$ nutrition significantly influenced the LAl of pigeon pea and higher LAl was recorded at $15 \mathrm{~kg} \mathrm{ZnSO}$. Seed polymer coating with $\mathrm{ZnSO}_{4}+\mathrm{B}+\mathrm{FeSO}_{4}+$ ammonium molybdate each at $2 \mathrm{~g} \mathrm{~kg}^{-1}$ seed followed by foliar application of $\mathrm{ZnSO}_{4}+\mathrm{B}+\mathrm{FeSO}_{4}+$ ammonium molybdate $(0.5+0.2+0.5+0.1$ per cent $)$ at 50 DAS and 60 DAS recorded significantly higher LAI in chick pea (Shinde et al., 2017).

Akay (2011) reported that application of $\mathrm{Zn} 1 \mathrm{~kg}$ $\mathrm{ha}^{-1}$ significantly enhanced the chlorophyll content in chickpea. Application of $\mathrm{B} 4 \mathrm{\mu g} \mathrm{g}^{-1}$ resulted in increase in chlorophyll and carotenoid content in mung bean (Seth and Aery, 2014). Rahdari et al. (2013) reported that in soybean, chlorophyll and carotenoid content increased with the application of $\mathrm{Zn} 200 \mu \mathrm{M}$. Seed polymer coating with $\mathrm{ZnSO}_{4}+$ $\mathrm{B}+\mathrm{FeSO}_{4}+$ ammonium molybdate each at $2 \mathrm{~g} \mathrm{~kg}^{-}$ ${ }^{1}$ seed along with two foliar sprays $(0.5+0.2+0.5$ +0.1 per cent) recorded significantly higher chlorophyll content in chick pea (Shinde et al., 2017). Samreen et al. (2017) reported that in mung bean, the highest chlorophyll content was observed at $0.2 \mu \mathrm{M}$ concentration of $\mathrm{Zn}$. Foliar nutrition of potassium nitrate 2 per cent + boric acid $50 \mathrm{ppm}$ $+\mathrm{ZnSO}_{4} 1$ per cent at 30 days after sowing (DAS) and 60 DAS significantly enhanced the total chlorophyll content in soybean (Gowthami et al., 2018). In pigeon pea, foliar application of 0.5 per cent $\mathrm{ZnSO}_{4}$ resulted in 3 to 8 per cent increase in chlorophyll content (Purushottam et al., 2018).

Mahilane and Singh (2018) observed higher crop growth rate (CGR) with the application of $\mathrm{Zn} 7.5$ $\mathrm{kg} \mathrm{ha}^{-1}$. In black gram, foliar application of $\mathrm{ZnSO}_{4}$ 0.3 per cent and $\mathrm{H}_{3} \mathrm{BO}_{3} 0.2$ per cent recorded significantly higher $C G R$ and relative growth rate (RGR) than control (Akshata, 2013).

Effect of $\mathrm{Zn}$ and $\mathrm{B}$ nutrition on growth parameters of pulses: In sandy loam soils and alfisols, soil application of $12.5 \mathrm{~kg} \mathrm{ZnSO} \mathrm{Zn}_{4}$ significantly enhanced the plant height in cowpea (Nagaraju and Yadahalli, 1996). Masuthi (2005) revealed that cowpea seeds pelleted with $\mathrm{ZnSO}_{4}$ increased the number of green leaves compared to control. Patel et al. (2011) revealed that application of $\mathrm{ZnSO}_{4} 25 \mathrm{~kg} \mathrm{ha}^{-1}$ significantly enhanced branches per plant in rainfed cowpea. Usman et al. (2014) reported that seed treatment with $\mathrm{ZnSO}_{4}$ significantly increased the pod bearing branches in green gram. Application of 0.2 per cent $\mathrm{ZnSO}_{4}$ along with 1 per cent each $\mathrm{Ca}, \mathrm{S}$ and $\mathrm{Mg}$ significantly enhanced the growth parameters in black gram (Lakshmi et al., 2017). Kuldeep et al. (2018) observed that $\mathrm{Zn}$ nutrition had positive effect on growth attributes of chick pea and it was observed that application of $\mathrm{Zn} 5 \mathrm{~kg} \mathrm{ha}^{-1}$ recorded higher number of branches per plant and DMP at harvest compared to $\mathrm{Zn}$ applied at 2.5 and $1.25 \mathrm{~kg} \mathrm{ha}^{-1}$. Praveena et al. (2018) reported that foliar application of 0.2 per cent $B$ at 20 and 35 DAS along with basal soil application of $\mathrm{ZnSO}_{4} 5 \mathrm{~kg} \mathrm{ha}^{-1}$ recorded significantly higher plant height, branches per plant and DMP per plant. Seed priming with $\mathrm{ZnSO}_{4} 0.05$ per cent for $4 \mathrm{~h}$ recorded significantly higher number of branches and green leaves and DMP per plant at harvest in grain cowpea (Raj, 2019).

Similar to that of $\mathrm{Zn}$, B nutrition also had significant effect on growth attributes of pulses. Foliar application of 02 per cent $B$ in green gram significantly improved the plant height and dry weight in green gram (Dixit and Elamathi, 2007). Kaisher et al. (2010) reported that in boron deficient sandy loam soil, application of B $5 \mathrm{~kg} \mathrm{ha}^{-1}$ significantly improved the plant height and number of branches per plant in mung bean. Foliar application of 0.2 per cent B as borax at 20 DAs and 35 DAS with the soil application of $\mathrm{Zn}$ recorded significantly higher plant height $(64.16 \mathrm{~cm})$ and dry weight per plant $(8.48 \mathrm{~g})$ at 60 DAS (Praveena et al., 2018). Mahadule et al. (2019) revealed that foliar application of boric acid either at 0.4 per cent or 0.6 per cent at 25 and 55 days after sowing recorded significantly higher number of branches in French bean.

Effect of $\mathrm{Zn}$ and $\mathrm{B}$ nutrition on nodulation in pulses: Zinc plays a major role in $\mathrm{N}$ fixation through nodule formation (Nandwall et al.,1990; Balusamy et al.,1996). Khorgamy and Farina (2009) reported that in chick pea, application of $\mathrm{ZnSO}_{4} 20 \mathrm{~kg} \mathrm{ha}{ }^{-1}$ markedly increased the root nodulation. Das et al. (2012) observed that, Zn plays a major role in leg haemoglobin synthesis 
and also observed that nodule number, size, leghaemoglobin content and dry weight of nodules depend on the $\mathrm{Zn}$ availability. Application of $\mathrm{Zn} 5$ $\mathrm{kg} \mathrm{ha}^{-1}$ resulted in 91 per cent enhancement in nodulation in soybean (Chauhan et al., 2013). Soil application of $15 \mathrm{~kg} \mathrm{Zn} \mathrm{ha-1}$ recorded higher number of nodules, effective nodules and nodule fresh weight per plant in cowpea (Upadhyay and Singh, 2016). However, Debnath et al. (2018) observed that, soil application of $\mathrm{Zn} 7.5 \mathrm{~kg} \mathrm{ha}^{-1}$ along with recommended dose of fertilizers recorded greater number of nodules per plant in cowpea. In cluster bean, nodule number and nodule fresh weight were greatly influenced by soil application of $\mathrm{Zn} 5$ $\mathrm{kg} \mathrm{ha}^{-1}$ (Kuniya et al., 2018).

Boron had significant effect on symbiotic $\mathrm{N}$ fixation. Bolanos et al. (1994) reported that absence of $B$ in the culture medium resulted in reduction in the number of nodules and variations in nodule development.

Boron is essential for the cell wall maintenance of nodule and symbiosome development (Bolanos et al., 2001). Subasinghe et al. (2003) observed that $B$ had a positive effect on nodulation and observed that up to $4 \mathrm{ppm}$, B enhanced the dry matter content and nodulation, but beyond $4 \mathrm{ppm}$ it had negative impact. Noor and Hossain (2007) also revealed that $B$ is essential for nodulation and $\mathrm{N}$ fixation in legumes. Application of $\mathrm{B} 0.5 \mathrm{~kg}$ ha $^{-1}$ significantly enhanced the $\mathrm{N}$ fixation in cowpea and ground nut by 89 per cent and 126 per cent, respectively over control, however higher dose $\left(1 \mathrm{~kg} \mathrm{ha}^{-1}\right)$ significantly reduced the $\mathrm{N}$ fixation in cowpea and groundnut (Yakubu et al., 2010). Nodule number, nodule weight and size of nodule improved with B $2.86 \mathrm{mg} \mathrm{L}^{-1}$, however higher level of $B 4.86 \mathrm{mg} \mathrm{L}^{-1}$ significantly reduced the nodule number, size and weight in pea (Mehmood et al., 2011). Parry et al. (2016) reported that application of $30 \mathrm{~kg} \mathrm{~S}+2 \mathrm{~kg} \mathrm{~B} \mathrm{ha}^{-1}$ recorded higher number of nodules per plant, nodule fresh and dry weight in garden pea. In black gram, the highest number of nodules per plant and nodule dry weight was observed in the treatment receiving 0.2 per cent borax along with 0.1 per cent Zn EDTA, 2 per cent urea and 2 per cent single super phosphate (Meena et al., 2017). Quddus et al. (2018) observed that nodulation increased with increase in rate of $B$ application and the highest number of nodules was observed, when B was applied @ 2 kg ha-1. Raj (2019) reported that cowpea seeds pelleted with borax recorded higher number of total nodules and effective nodules per plant compared to seed priming with $\mathrm{ZnSO}_{4}$.

Effect of $\mathrm{Zn}$ and $\mathrm{B}$ nutrition on nutrient uptake in pulses: Hassanein et al. (1999) reported that $B$ nutrition enhanced the $B$ content in cowpea and they also found that with the increase in concentration an increase in $B$ content was observed in different plant parts. Kumar and Sidhu (2013) reported that $B$ uptake by soybean increased with increasing B level up to $0.44 \mathrm{mg} \mathrm{kg}^{-1}$ and decreased after that. Ganie et al. (2014) opined that B nutrition significantly improved the N, P, K, S and B uptake in French bean. Quddus et al. (2018) reported that the highest $B$ uptake was recorded in filed pea when boron was applied @ 2kg ha-1 along with $3 \mathrm{~kg} \mathrm{Zn} \mathrm{ha-1}$. Debnath et al. (2018) who observed that application of $B$ along with recommended dose of fertilizers increased the $B$ uptake in grain cowpea. Raj (2019) observed that seed pelleting with borax significantly improved the $B$ uptake in grain cowpea compared to control and it was also observed that compared to seed pelleting with $50 \mathrm{mg}$ borax $\mathrm{kg}^{-1}$ seed, $100 \mathrm{mg}$ borax $\mathrm{kg}^{-1}$ seed recorded higher uptake of $B$.

Seema et al. (2014) reported that $N$ content in seeds significantly increased with the application of $\mathrm{Zn}$ in green gram. Umesh and Shankar (2013) revealed application of $Z \mathrm{n} 12.5 \mathrm{~kg} \mathrm{ha}^{-1}$ significantly enhanced the $\mathrm{Zn}$ uptake in pigeon pea. Application of $5 \mathrm{~kg} \mathrm{Zn}$ along with $60 \mathrm{~kg} \mathrm{P}_{2} \mathrm{O}_{5}$ and $20 \mathrm{Kg} \mathrm{S} \mathrm{ha}^{-1}$ recorded higher $\mathrm{N}$ and $\mathrm{P}$ uptake by seed and stover in pea (Singh et al., 2015). Application of $\mathrm{ZnSO}_{4}$ $10 \mathrm{~kg} \mathrm{ha}^{-1}$ recorded higher $\mathrm{N}, \mathrm{P}, \mathrm{K}$ and $\mathrm{Zn}$ uptake in green gram (Ranpariya et al., 2017). Foliar application of $\mathrm{ZnSO}_{4} 0.05$ per cent increased the $\mathrm{Zn}$ uptake from 18 to 37 per cent (Purushottam et al., 2018). Grain cowpea seeds primed in 0.05 per cent $\mathrm{ZnSO}_{4}$ for $4 \mathrm{~h}$ recorded higher total uptake of N, P and K by crop (Raj, 2019).

Effect of $\mathrm{Zn}$ and $\mathrm{B}$ nutrition on yield of pulses: Zinc fertilization had positive effect on the yield of pulses. Application of Zn $5 \mathrm{~kg} \mathrm{ha}^{-1}$ along with S 60 $\mathrm{kg} \mathrm{ha}^{-1}$ recorded 67 per cent higher seed yield over control in mung bean (Mali et al., 2003). Khorgamy and Farina (2009) opined that soil application of $\mathrm{ZnSO}_{4} 20 \mathrm{~kg} \mathrm{ha}^{-1}$ markedly enhanced the seed yield in chickpea cultivars. Foliar application of 0.4 per cent $\mathrm{Zn}$ at pre flowering and post pod forming stage increased the seed yield by 16.2 per cent over control in lentil (Singh and Bhati, 2013). Umesh and Shankar (2013) revealed that soil application of $\mathrm{ZnSO}_{4} 12.5 \mathrm{~kg} \mathrm{ha}^{-1}$ along with the recommended dose of NPK recorded the highest seed yield $\left(1759 \mathrm{~kg} \mathrm{ha}^{-1}\right)$ in pigeon pea. Malik et al. (2015) revealed that significantly higher seed yield per plant $(78.2 \mathrm{~g})$ was recorded with foliar nutrition of $20 \mathrm{ppm} \mathrm{Zn}$. In black gram, foliar nutrition of secondary nutrients viz., $\mathrm{CaNO}_{3}, \mathrm{MgNO}_{3}$ and $S$ each at one per cent along with 0.2 per cent $\mathrm{ZnSO}_{4}$ at 25 DAS and 45 DAS recorded the highest seed yield (Lakshmi et al., 2017). Kuniya et al. (2018) indicated that soil application of $\mathrm{Zn} 5$ $\mathrm{kg} \mathrm{ha}^{-1}$ greatly enhanced the seed and stover yield of cluster bean.

Boron is essential for pod and seed formation in pulses (Vitosh et al., 1997) Sakal et al. (1998) reported that in calcareous soil, soil application of 
2.0 and $2.5 \mathrm{~kg} \mathrm{ha}^{-1}$ increased the seed yield of black gram by 33 per cent and chickpea by 38 per cent, respectively. Soil application of $B 1 \mathrm{~kg} \mathrm{ha}^{-1}$ alone or in combination with $S 30 \mathrm{~kg} \mathrm{ha}^{-1}$ were found best for higher yield in soybean (Sarker et al., 2002). Foliar application of borax 0.2 per cent at vegetative and flowering stage significantly enhanced the seed yield in mung bean compared to control (Patra and Bhattacharya, 2009). Combined application of $\mathrm{B} 1.5 \mathrm{~kg} \mathrm{ha}^{-1}+\mathrm{Zn} 3 \mathrm{~kg} \mathrm{ha}^{-1}$ enhanced the seed yield in lentil (Quddus et al., 2014). Chatterjee and Bandyopadhyay (2017) observed that foliar nutrition of $B 1.5 \mathrm{~g} \mathrm{~L}^{-1}$ at four weeks after planting (WAP) recorded 39 per cent higher pod yield per plant over control in vegetable cowpea. Adhikary et al. (2018) reported that in lentil, foliar spray of 0.5 per cent B at 15 DAS, 40 DAS and flower initiation stage recorded 26.98 per cent higher seed yield in lentil. Soil application of $\mathrm{Zn} 5 \mathrm{~kg} \mathrm{ha}^{-1}$ followed by foliar spray of B 0.5 per cent at 20 DAS and 35 DAS registered the highest seed yield $\left(2.18 \mathrm{t} \mathrm{ha}^{-1}\right)$ in green gram (Praveena et al., 2018).

Effect of $\mathrm{Zn}$ and $\mathrm{B}$ nutrition on protein content of pulses: Taliee and Sayadian (2000) opined that due to the role of $\mathrm{Zn}$ in $\mathrm{N}$ metabolism, the seed quality was improved. Pigeon pea seeds treated with $\mathrm{ZnSO}_{4} 4 \mathrm{~g} \mathrm{ha}^{-1}$ seed had significant impact on grain protein content (Sharma et al., 2010). Chavan et al. (2012) opined that compared to soil application of Zn $20 \mathrm{~kg} \mathrm{ha}^{-1}$ the higher dose of $40 \mathrm{~kg} \mathrm{ha}^{-1}$ registered the highest protein content in cowpea. Application of $10 \mathrm{~kg}$ $\mathrm{Zn} \mathrm{ha}{ }^{-1}$ recorded the highest protein content in mung bean (Ram and Katiyar, 2013). Higher protein content was observed with soil application of $\mathrm{Zn}$

$5 \mathrm{~kg} \mathrm{ha}^{-1}$ in cluster bean Kuniya et al. (2018). Raj (2019) observed that among the various seed invigouration methods, seed priming with $\mathrm{ZnSO}_{4}$ 0.05 per cent for $4 \mathrm{~h}$ recorded higher crude protein content of grain.

Debnath and Ghosh (2011) reported that B plays a major role in metabolism of protein and nucleic acids. Foliar application of Zn 2 ppm and B 2 ppm significantly enhanced the protein content in cowpea seeds (Salih, 2013). In French bean, the highest crude protein content was observed with the application of B $1.5 \mathrm{~kg} \mathrm{ha}^{-1}$ (Ganie et al., 2014).

\section{Conclusion}

Zinc and B nutrition significantly improves the physiological, growth and yield parameters and yield in pulses. The availability of these nutrients in soil depends on the texture of soil, nature and amount of clay present, soil organic matter, soil moisture and the relationship with the other nutrient elements present in the soil. All the three methods of application (soil, foliar and seed) show favourable results. However, the magnitude of $B$ and $\mathrm{Zn}$ response varies with crop, variety and also with the soil type. It has been observed that soil application of $B$ up to $2.5 \mathrm{~kg} \mathrm{ha}^{-1}$ gave positive response in pulses and foliar application up to 0.5 percent. The critical limit for B deficiency is less (15 ppm), sufficiency is $15-100 \mathrm{ppm}$ and toxicity is more than $200 \mathrm{ppm}$. The critical limit for $\mathrm{Zn}$ is 15 mg kg-1 of dry matter and the sufficiency range is more than $20 \mathrm{mg} \mathrm{kg}^{-1}$. The positive response $\mathrm{Zn}$ has been observed up to soil application of $5.5 \mathrm{Zn}$ $\mathrm{kg} \mathrm{ha}^{-1}$. The residual effect of $\mathrm{Zn}$ persists in the soil for four seasons in calcareous soils and six seasons in non-calcareous soil. Hence, based on soil test results, soil type and crop, $\mathrm{Zn}$ and $\mathrm{B}$ can be applied to enhance the production and productivity of pulses.

\section{REFERENCES}

1. Adhikary, P., Giri, S., Hansda, A., Saren, S., and Tudu, B. (2018). Effect of boron on growth and yield of lentil in alluvial soil. Int. J. Pure. Appl. Biosci. 6 (5):1171-1175.

2. Akay, A. (2011). Effect of zinc fertilizer applications on yield and element contents of some registered chickpeas varieties. Afr. J. Biotechnol. 10 (60): 12890 $-12896$.

3. Akshata, S. P. (2013). Effect of nutrients on physiology, yield and yield components and disease incidence in black gram (Vigna mungo (L.) Hepper) M.Sc. (Ag) thesis, University of Agricultural Sciences, Dharwad, 59p. Akshata, S. P. 2013. Effect of nutrients on physiology, yield and yield components and disease incidence in black gram (Vigna mungo (L.) Hepper) M.Sc. (Ag) thesis, University of Agricultural Sciences, Dharwad, 59p.

4. Aslam, M. I., Mahmood, H., Qureshu, R. H., Nawaz, S., and Akhtar. (2002). Salinity tolerance of rice as affected by boron nutrition. Pak. J. Soil Sci. 21: 110 118.

5. Auld, D. S. (2001). Zinc coordination sphere in biochemical zinc sites. Biometals 14: 271-313.

6. Bolanos, L., Cebrian, A., Redonto-Nieto, N., Rivilla, R., and Bonilla, I. (2001). Lectin like glycoprotein PsNLEC-1 is not correctly glycosylated and targeted in boron deficient pea nodules. Mol. Plant Microbe Interaction 14: 663-670.

7. Bolanos, L., Esteban, E., De Lorenzo, C., FernandezPascual, M., de Felipe, M. R., Garate, A., and Bonilla, I. (1994). Essentiality of boron for symbiotic dinitrogen fixation in pea (Pisum sativum) rhizobium nodules. Plant Physiol. 104: 85-90.

8. Balusamy, M., Ravichandran, V. K., and Balasubramanian, N. (1996). Effect of zinc, boron and FYM on growth and yield of soybean. Madras Agric. J. 83 (3): 134-136.

9. Baybordi, A. (2006). Effect of Fe, Mn, Zinc and Cu on the quality and quantity of wheat under salinity stress. J. Water Soil Sci. 17: 140-150.

10.Cakmak, I. (2000). Possible roles of zinc in protecting plant cells from damage by reactive oxygen species. New Phytologist 146 (2): 185-205.

11.Cakmak, I. (2008). Enrichment of cereal grains with zinc: Agronomic or genetic biofortification. Plant Soil 302: 1-17.

12.Chatterjee, R. and Bandyopadhyay, S. (2017). Effect 
Raj, A.B. and Raj, S.K. / J. Appl. \& Nat. Sci. 11(3): 673 - 679 (2019)

of boron, molybdenum and biofertilizers on growth and yield of cowpea (Vigna unguiculata L. Walp.) in acid soil of eastern Himalayan region. J. Saudi Soc. Agric. Sci. 11: 26-31.

13.Cheng, C. and Rerkasem, B. (1993). Effects of boron on pollen viability in wheat. Plant Soil 155: 313-315.

14.Chauhan, S., Titov, A., and Tomar, D. S. (2013). Effect of potassium sulphate and zinc on growth, yield and oil content in soybean (Glycine max L.) in Vertisols of central India. Indian J. Appl. Res. 3 (6): 489-491.

15.Chavan, A. S., Khafi, M. R., Raj, A. D., and Parmar, R. M. (2012). Effect of potassium and zinc on yield, protein content and uptake of micronutrients on cowpea (Vigna unguiculata (L.) Walp. Agric. Sci. Digest 32: $175-177$.

16.Das, S., Pareek, N., Raverkar, K. P., Chandra, R., and Kaustav, A. (2012). Effectiveness of micronutrient application and Rhizobium inoculation on growth and yield of Chickpea. Int. J. Agric. Environ. Biotechnol. 5 (4): 445-452.

17.Debnath, P. and Ghosh, S. K. (2011). Determination of critical limit of available boron for rice in terai zone soils of West Bengal J. Indian Soc. Soil Sci. 59: 8286.

18.Debnath, P., Pattanaaik, S. K., Sah, D., Chandra, G., and Pandey, A. K. (2018). Effect of boron and zinc fertilization on growth and yield of cowpea (Vigna unguiculata Walp.) in Inceptisols of Arunachal Pradesh. J. Indian Soc. Soil Sci. 66 (2): 229-234.

19.Dell, B. L. and Huang, L. (1997). Physiological response of plants to low boron. Plant Soil 193: 103120

20.Dixit, P. M., and Elamathi, S. (2007). Effect of foliar application of DAP, micronutrients and NAA on growth and yield of green gram (Vigna radiata L.). Legume Res. 30: 305-307.

21.Evans, P. and Halliwell, B. (2001). Micronutrients; oxidant/antioxidant status. Br. J. Nutr. 85: 567-574.

22.Ganie, M. A., Akhter, F., Bhat, M. A., and Najar, G. R. (2014). Growth yield and quality of French bean (Phaseolus vulgaris L.) as influenced by sulphur and boron application on inceptisols of Kashmir. Bioscan 9 (2): 513-518.

23.Gowthami, P., Rao, G. R., Rao, K. L. N., and Lal, A. M. (2018). Effect of foliar application of potassium, boron and zinc on quality and seed yield in soybean. Int. J. Chem. Stud. 6(1): 142-144.

24.Hassanein, R. A., Dowidar, A.E., Zaky, L.M., and ElMashad, A. A. (1999). Effect of foliar treatment with boron and Zinc on physiological responses of Cow Pea (Vigna sinensis Cv. Cream 7), I- Growth parameters, auxins, growth inhibitor content, yield and their protein pattern. Egypt. J. Physiol. Sci. 23: 415-442.

25.Hussain, M., Khan, M. A., Khan, M. B., Farooq, M., and Farooq, S. (2012). Boron application improves the growth, yield and net economic return of rice. Rice Sci. 19: 259-262.

26.Kaisher, M. S., Rahman, M. A., Amin, M. H. A., Amanullah, A. S. M., and Ahsanullah, A. S. M. (2010). Effects of sulphur and boron on the seed yield and protein content of mungbean. Bangladesh Res. Publ. J. 3: 1181-1186.

27.Khorgamy, A. and Farina A. (2009). Effect of phosphorus and zinc fertilization on yield and yield components of chick pea cultivars. Afr. Crop Sci. Conf. Proc. 9: 205-208.

28.Kuldeep, Kumavat, P.D., Bhadu, V., Sumeriya, H.K., and Kumar, V. (2018). Effect of iron nad zinc nutrition on growth and yield of chickpea (Cicer arietinum L.). Int.J. Curr. Microbiol. Appl. Sci. 7 (8): 2837-2841.

29.Kumar, D and Sidhu, S.S. (2013). Response of soybean to soil applied sulphur and boron in a calcareous soil. J. Plant Nutr. 36 (11): 1795-1805.

30.Kuniya, N., Chaudhary, N., and Patel, S. 2018. Effect of sulphur and zinc application on growth, yield attributes, yield and quality of summer clusterbean [Cyamopsis tetragonoloba (L.)] in light textured soil. IJCS. 6 (1): 1529-1532.

31.Lakshmi, E. J., Rameshbabu P. V., Reddy, G. P., Umamaheswari, P., and Reddy, A. P. K. (2017). Effect of foliar application of secondary nutrients and zinc on growth and yield of black gram. Int. J. Chem. Stud. 5 (6):944-947.

32.Latef, A. A. H., Abu Alhmad, M. F., Abdelfattah, K. E. (2017). The possible roles of priming with $\mathrm{ZnO}$ nanoparticles in mitigation of salinity stress in Lupine (Lupinus termis) plants. J. Plant Growth Reg. 36: 6070.

33.Mahadule, P.A., Jagadhani, A.D., Jagtap, P.B., Tamboli, B.D., and Kadam, M. 2019. Effect of foliar sprays of boron on growth and yield of French bean (Phaseolus vulgaris L.) in Entisol. Int. J Chem. Stud. 7 (2): 1885-1888.

34.Mahilane, C. and Singh, V. (2018). Effect of zinc and molybdenum on growth, yield attributes, yield and protein in grain on summer blackgram (Vigna mungo L.). Int. J. Curr. Microbiol. Appl. Sci. 7 (1): 1156-1162.

35.Mali, G. C., Sharma, N. N., Acharya, H. K., Gupta, S. K., and Gupta, P. K. (2003). Response of pigeon pea to $S$ and $Z n$ fertilization on Vertisols in South eastern plain of Rajasthan. Proceedings of National symposium on Arid Legumes for Food Nutrition Security and Promotion Trade, 15-16 May 2002, Hissar, pp.267271.

36.Malik, K., Kumar, S., and Arya, K. P. S. (2015). Effect of $\mathrm{Zn}$, Mo and urea on growth and yield of mung bean (Vigna radiata L. Wilczek). Adv. Res. J. Crop Improv. 6 (1): 58-62.

37.Marschner, H. (1995). Mineral Nutrition of Higher Plants. Academic Press, San Diego, USA, pp. 379396.

38.Masuthi, D. A. 2005. Effect of phosphorus, zinc and boron on fruit set, seed yield and quality of vegetable cowpea (Vigna anguiculata L.). M.Sc.(Ag) thesis, University of Agricultural Sciences, Dharwad, Karnataka, 108p.

39.Meena, D., Bhushan, C., Shukla, A., Chaudhary, S., and Sirazuddin. (2017). Effect of foliar application of nutrients on nodulation, yield attributes, yield and quality parameters of urd bean (Vigna mungo (L.) Hepper). Bioscan 12(1): 411-414

40.Mehmood, F., Qasim, M.,Khan, Z.D., and Raza, S.H. 2011. Effect of exogenous supply of boron on nodule development in pea. Pak. J. Bot. 43: 2115-2118.

41.Moeinian, M. R., Zargari, K., and Hasanpour, J. (2011). Effect of boron foliar spraying application on quality characteristics and growth parameters of wheat grain under drought stress. Am. Eur. J. Agric. Environ. Sci. 1: 593-599.

42.Mondal, M., Rahman, M. A., Akter, M. B., and Fakir, M. S. A. (2011). Effect of foliar application of nitrogen and micronutrients on growth and yield in mung bean. Legume Res. 34 (3): 166-171.

43.Nagaraju, A.P. and Yadahalli.(1996). Response of 
cowpea (Vigna unguiculata) to sources and levels of phosphorus and zinc. Indian J. Agron. 41(1): 88-90.

44.Nandwall, A. S., Dabas, S., Bharti, S., and Yadav, B. D. (1990). Zinc effect on nitrogen fixation and cluster bean yield. Ann. Arid Zone 29 (2): 99-103.

45.Noor, S. S. and Hossain, M. A. (2007). Effects of boron and molybdenum on the yield of chick pea. $J$. Agric. Rural Dev. 5 (1and 2): 17-24.

46.Ozturk, L., Yazici, M. A., Yucel, C., Torun, A., Cekic, C., Bagci, A., Ozkan, H., Braun, H. J., Sayers, Z., and Cakmak, I. (2006). Concentration and localization of zinc during seed development and germination in wheat. Physiol. Plant 128: 144-152.

47.Pandey, N., Pathak, G. C., and Sharma, C. P. 2006. Zinc is critically required for pollen function and fertilization in lentil. J. Trace Elements Med. Biol. 20: 8996.

48.Parr, A. and Loughman, B. C. (1983). Boron and membrane function in plants. In: Robb, D. A. and Pierpoint, W. S. (eds), Metals and Micronutrients, Uptake and Utilization by Plants. Academic Press, New York, pp. 87-107.

49.Parry, F. A., Chattoo, M. A., Magray, M., Ganie, S. A., Dar, Z. M., and Masood, Effect of different levels of sulphur and boron on growth and nodulation of garden pea (Pisum sativum L.). Legume Res. 39 (3): 466-469.

50.Patel, M, M., Patel, I.C., Patel, R.I., and Acharya, S. 2011. Effect of zinc and iron on yield and yield attributes of rainfed cowpea (Vigna unguiculata L. Walp). Ann. Arid Zone 50 (1): 17-19.

51.Patra, P. K. and Bhattacharya, C. 2009. Effect of different levels of $B$, Mo on growth and yield of mung bean [Vigna radiate(L) Wilczek (cv.Baisakhi Mung)] in red and laterite one of West Bemgal. J. Crop Weed 5 (1):111-114.

52.Praveena, R., Ghosh, G., and Singh, V. (2018). Effect of foliar spray of boron and different zinc levels on the growth and yield of Kharif green gram (Vigna radiata). Int. Curr. Microbiol. Appl. Sci. 7 (8): 14221428.

53.Purushottam, B. K., Puhup, C. S. K., Kumar, and Sodi, B. (2018). Effect of irrigation scheduling and zinc application on chlorophyll content, zinc content, uptake and yield of chickpea (Cicer arietinum L.). J. Pharmacognosy Phytochem. 7 (1): 1834- 1837

54.Quddus, M. A., Hossain, M. A., Naser, H. M., Naher, N., and Khatun, F. 2018. Response of chickpea varieties to Boron application in calcareous and terrace soils of Bangladesh. Bangladesh J. Agric. Res. 43 (4): 543-556.

55.Quddus, M. A., Naser, H. M., Hossain M. A., and Abdulhossain M. (2014). Effect of zinc and boron on yield and yield contributing characters of lentil on low ganges river flood plain soil at Madaripur Bangladesh. Bangladesh J. Agric. Res. 39 (4):591-603.

56.Raj, A.B. (2019). Seed invigouration for yield enhancement in grain cowpea (Vigna unguiculate $\mathrm{L}$. Walp). M.Sc. (Ag) thesis, Kerala Agricultural University, Thrissur, 155p.

57.Rahdari, P., Hoseini, S. M., and Movafegh, S. 2013. Alteration in metabolic process of Glycine max. L. following $\mathrm{Zn}$ rate changes. Int. J. Agron. Plant Prod. 4 (3): 589-594

58.Ram, S. and Katiyar, T. P. S. (2013). Effect of sulphur and zinc on the seed yield and protein content of summer mungbean under arid climate. Int. J. Sci.
Nat. 4 (3): 563-566.

59.Ranpariya, V.S., Polaro, K.B., Hirpara, D.V., and Bodax, KH. (2017). Effect of potassium, zinc and FYM on content and uptake of nutrient in seed of summer green gram (Vigna radiata L.) and postharvest soil fertility under medium black calcareous soil. Int. J. Chem. Stud. 5 (5): 1055-1058.

60.Rerkasem, B. (1996). Boron and plant reproductive development. Sterility in Wheat in Subtropical Asia: extent, causes and solutions. 72: 32-34.

61.Salih, H. O. (2013). Effect of foliar fertilization of $\mathrm{Fe}$, $\mathrm{B}$ and $\mathrm{Zn}$ on nutrient concentration and seed protein of Cowpea (Vigna unguiculate). J. Agric. Vet. Sci. 6 (3): 42-46.

62.Sakal, R. and Singh, A. P.1995. Boron research and agricultural production $\mathrm{In}$ : micronutrients research and agricultural production (Ed.) H. L. S. Tandon. Fertilizer and Consultation Organization, New Delhi, pp.1-31.

63.Samreen, T., Shah, H. U., Ullah, S., and Javid, M. (2017). Zinc effect on growth rate, chlorophyll, protein and mineral contents of hydroponically grown mungbeans plant (Vigna radiata). Arabian J. Chem. 10: 1802-1807.

64.Sarker S. K., Chowdhary M. A. H., and Zakir, H. M. (2002). Sulphur and boron fertilization on yield, quality and nutrient uptake by Bangladesh soybean- $4 \mathrm{~J}$. Biol.Sci.2 (11):729-733.

65.Schon, M. K., Novacky, A., and Blevins, D. G. (1990). Boron induces hyperpolarisation of sunflower root cell membranes and increases membrane permeability to $\mathrm{K}^{+}$. J. Plant Physiol. 93: 566-577.

66.Seema, C., Harvendra, S., Sandeep, S., and Vinay, S. (2014). Zinc requirement of green gram (Vigna radiata)-wheat (Triticum aestivum) crop sequence in alluvial soil. Indian J. Agron. 59 (1): 48-52.

67.Serrano, R. (1989). Structure and function of plasma membrane ATPase. Ann. Rev. Plant Physiol. 40: 6194.

68.Sharma, A., Nakul, H. T., Jelgeri, B. R., and Surwenshi, A. 2010. Effect of micronutrients on growth, yield and yield components in pigeonpea (Cajanus cajan L. Millsp.). Res. J. Agric. Sci. 1 (2): 142-144.

69.Seth, K. and Aery, N. C. 2014. Effect of boron on the contents of chlorophyll, carotenoid, phenol and soluble leaf protein in mung bean, Vigna radiate (L.) Wilezek. Proc. Natl. Acad. Sci. India Section Biol. Sci. 84 (3): 713-719.

70.Sharma, A., Nakul, H. T., Jelgeri, B. R., and Surwenshi, A. (2010). Effect of micronutrients on growth, yield and yield components in pigeonpea (Cajanus cajan L. Millsp.). Res. J. Agric. Sci. 1 (2): 142-144.

71.Shinde, P., Doddagoudar, S. R., and Vasudevan, S. N. (2017). Influence of seed polymer coating with micronutrients and foliar spray on seed yield of chickpea (Cicer arietinum L.). Legume Res. Int. J. 40 (4):132-135

72.Stevenson, F. J. and Cole, M. A. (1999). Cycles of Soil: Carbon, Nitrogen, Phosphorus, Sulfur, Micronutrients $\left(2^{\text {nd }} E d\right.$.). New York: John Wiley \& Sons.

73. Subasinghe, S., Dayatilake, G. A., and Senaratne, R. (2003). Effect of B, Co and Mo on nodulation, growth and yield of cowpea (Vigna unguiculata). Trop. Agric. Res. Ext. 6: 108-112.

74.Singh, A. K. and Bhati, B. P. (2013). Effect of foliar application of zinc on growth and seed yield of late sown lentil (Lens culinaris) Indian J. Agric. Sci. 83 
Raj, A.B. and Raj, S.K. / J. Appl. \& Nat. Sci. 11(3): 673 - 679 (2019)

(6):622-626.

75.Singh, D.K., Singh, A.K., Singh, S.K., Singh, M. and Srivastava, O.P. (2015). Effect of balanced nutrition on yield and nutrient uptake of pea (Pisum sativum L.) under Indo Gangetic plains of India. The Bioscan 10 (3): 1245-1249.

76.Taliee, A. and Sayadian, K. (2000). Effect of supplemental irrigation and plant nutrient in chickpea (dry farming). J. Agron. Crop Sci, 2: 213-218.

77.Tariq, M. and Mott C. J. B. 2007. The significance of boron in plant nutrition and environment - $\mathrm{A}$ review. J. Agron. 6: 1-10.

78.Thamke, S. S. (2017). Studies on effect of graded levels of potassium and zinc on growth, yield, nutrient uptake and quality of pigeon pea. Ph.D. thesis, Vasantrao Naik Marathwada Krishi Vidyapeeth, Parbhani, $106 p$.

79.Tripathy, S. K., Patra, A. K., and Samui, S. C. (1999). Effect of micronutrient on nodulation, growth, yield and nutrient uptake by groundnut (Arachis hypogaea). Indian J. Plant Physiol. 4: 207-209.

80.Umesh, M. R. and Shankar M. A. (2013). Yield per- formance and profitability of pigeon pea (Cajanus cajan L.) varieties under different nutrient supply levels in dryland alfisols of Karnataka. Indian J. Dryland Agric. Res. Dev.28 (1):63-69.

81.Upadhyay, R. G. and Singh, A. (2016). Effect of nitrogen and zinc on nodulation, growth and yield of cowpea (Vigna unguiculata). Legume Res. Int. J. 39 (1): 149-151.

82.Usman, M., Tahir, M., and Majeed, M. A. 2014. Effect of zinc sulphate as soil application and seed treatment on green gram (Vigna radiata L.). Pak. J. Life Soc. Sci. 12 (2): 87-91.

83.Vitosh, M. L., Wameke, D. D., and Lucas. (1997). Boron Mishigan State University Extension Soil and Management Fertilizer. Available : http:/l www.Msue.msu.EDV[01-07-2019].

84.Yakubu, H., Kwari, J. D., and Tekwa, J. A. (2010). Nodulation and $\mathrm{N}_{2}$ fixation by grain legumes as affected by boron fertilizer in Sudano-Sahelian zone of North eastern Nigeria American Eurasian J. Agric. Enviro. Sci. 8 (5): 514-519. 